\title{
Shared Leadership in Mechanical Engineering-Centric Capstone Design Teams: A Comparison of Military and Civilian Engineering Programs
}

\section{Lt. Col. Brian J Novoselich P.E., Virginia Tech}

Brian Novoselich is an active duty Lieutenant Colonel in the United States Army and currently a Ph.D. Candidate in the Department of Engineering Education at Virginia Tech. His is a former assistant professor at the United States Military Academy and will return to the department in the fall of 2016. His research interests include capstone design teaching and assessment, undergraduate engineering student leadership development, social networks.

\section{Dr. David B Knight, Virginia Tech Department of Engineering Education}

David Knight is an Assistant Professor in the Department of Engineering Education and affiliate faculty with the Higher Education Program, Center for Human-Computer Interaction, and Human-Centered Design Program. His research focuses on student learning outcomes in undergraduate engineering, learning analytics approaches to improve educational practices and policies, interdisciplinary teaching and learning, organizational change in colleges and universities, and international issues in higher education. 


\section{Shared Leadership in Mechanical Engineering-Centric Capstone Design Teams: A comparison of military and civilian engineering programs.}

\section{Introduction}

There is a continuing call for the development of engineers who can become leaders in helping solve the world's grand challenges. ${ }^{1-3}$ Although many programs look toward the capstone design experience to help build students' professional skills, ${ }^{4-6}$ which includes leadership, ${ }^{7}$ student preparation for the leadership challenges associated with the capstone design team experience may widely vary. Leadership scholars suggest that "shared leadership" may be a more effective leadership model than the hierarchical, individual leadership model that is typically used in teambased capstone design projects. ${ }^{8}$ The capstone experience replicates the creative, complex, and interdependent knowledge work for which shared leadership has been shown to be more effective. ${ }^{9}$ Unlike some of their civilian counterparts, military academies and military colleges often incorporate a highly developed leadership curriculum throughout the four-year college experience, ${ }^{10 ; 11}$ whereas civilian engineering universities generally tend to be less purposeful in their leadership development for engineering students. ${ }^{7}$ In both instances, little is known regarding how civilian and military undergraduate engineering students approach and share leadership in their formative, design experiences.

The purpose of this study is to examine institutional differences in the level of shared leadership enacted by senior-level capstone design teams within the mechanical engineering programs at two military and one civilian institution. This study specifically investigates institutional differences uncovered as a part of a larger study of shared leadership in undergraduate capstone design teams ( $\mathrm{see}^{12}$ ). This larger study sought to validate a model of leadership within the capstone design teams and further understand how sharing leadership related to team effectiveness. The current study specifically addressed the following research questions:

RQ1: What level of variation in shared leadership is explained by institution versus military/civilian differences for mechanical engineering-centric capstone design teams?

RQ2: What differences exist among mechanical engineering-centric capstone design teams from civilian and military institutions in shared leadership in terms of 1) the amount of leadership enacted, and 2) the level of leadership distribution within the teams?

\section{Review of the Literature}

Formative leadership experiences are critical to the long term development of engineers as future leaders. Various national level reports have expressed the need for technically minded leaders to help shape sustainable, technically sound solutions to the world's grand challenges (e.g. ${ }^{1 ; 3}$ ). To help develop the next generation of engineering leaders, engineering educators are tasked with imparting a basic understanding of leadership principles for undergraduate engineers ${ }^{2}$ that may 
set the foundation for increased leadership practice throughout their careers. ${ }^{13}$ Senior-level, capstone design courses have routinely been a common venue for teaching engineering professional skills,${ }^{6}$ to include engineering leadership. ${ }^{14}$ Little is known, however, regarding how students enact leadership within these formative experiences; scholars assert adequate models of engineering leadership do not exist. ${ }^{15}$ In the context of design, observing and understanding a phenomenon is often a necessary pre-cursor to developing tools to support students and practitioners. ${ }^{16}$ The leadership differences investigated in this study may help inform future models of engineering leadership.

Engineering students entering military careers may experience formative engineering leadership experiences in ways different from their civilian counterparts. As the single largest institution-level producer of commissioned officers for each branch of service ${ }^{17}$, the military academies are a primary source of undergraduate education for the military's future leaders. ${ }^{10}$ The three academies provide full-immersion programs for their students, preparing them for the rigors of military leadership in addition to an undergraduate education, which includes engineering. ${ }^{10}$ These military leadership programs may differ significantly from leadership programs at civilian institutions. ${ }^{11}$ Consequently, there is the potential for differences in how military students develop when compared to their civilian-educated counterparts. ${ }^{18}$

Through separate career paths, military and civilian engineering students may be required to work together in graduate degree programs and in professional settings later in their careers. Insights regarding differences in formative engineering leadership experiences gained from this study may inform these future work experiences. For engineering educators and practicing engineers, a contribution of this study is a purposeful examination of two very different models of leadership development that may facilitate further inquiry into how aspects of each may be beneficial.

\section{Leadership Framework}

The Full Range of Leadership model informed this study of leadership differences. This leadership model has been in existence for over two decades (see ${ }^{19}$ ) and is operationalized with the well-established Multifactor Leadership Questionnaire (MLQ). ${ }^{20}$ The Full Range of Leadership model was particularly well suited for the study because of its origins in both military and civilian settings ${ }^{21}$ which allowed for construct validity ${ }^{22}$ within both military and civilian design teams. The leadership factors that comprise the model were originally developed through interviews with a combination of high ranking military officers and corporate leaders. A teamlevel version of the model has also been investigated for both civilian and military teams. ${ }^{23}$ Previous literature has indicated the Full Range of Leadership model's applicability for engineering contexts, e.g. ${ }^{9 ; 24}$.

Using factor analysis in preliminary examination of the Full Range of Leadership model for capstone design teams, Novoselich and Knight ${ }^{9 ; 12}$ identified three scale variables from the nine leadership factors that comprise the model - transformational/contingent reward (TCR), active management by exception (MEA) and passive-avoidant (PA) - that occurred within the capstone design team context. These leadership scales are conceptually similar but distinct from the transformational, transactional, and laissez-faire scales contained the original Full Range of 
Leadership model ${ }^{9}$ and explored in previous examinations of the Full Range of Leadership model, e.g. ${ }^{23 ; 25 ; 26}$. TCR leadership develops team member strengths, maintains a compelling vision, shows strong sense of purpose, and instills pride in team members. ${ }^{12}$ MEA leadership involves negative reinforcement and a consistent focus on both maintaining standards and tracking mistakes among team members. ${ }^{12 ; 27 ; 28}$ PA leaders either delay action until serious issues arise or demonstrate a total absence of involvement, especially when needed. ${ }^{25}$ In the model, leaders exhibit all three leadership scales, or forms of leadership, which vary in both effectiveness and activity. The original and modified versions of the model are shown in Figure 1.

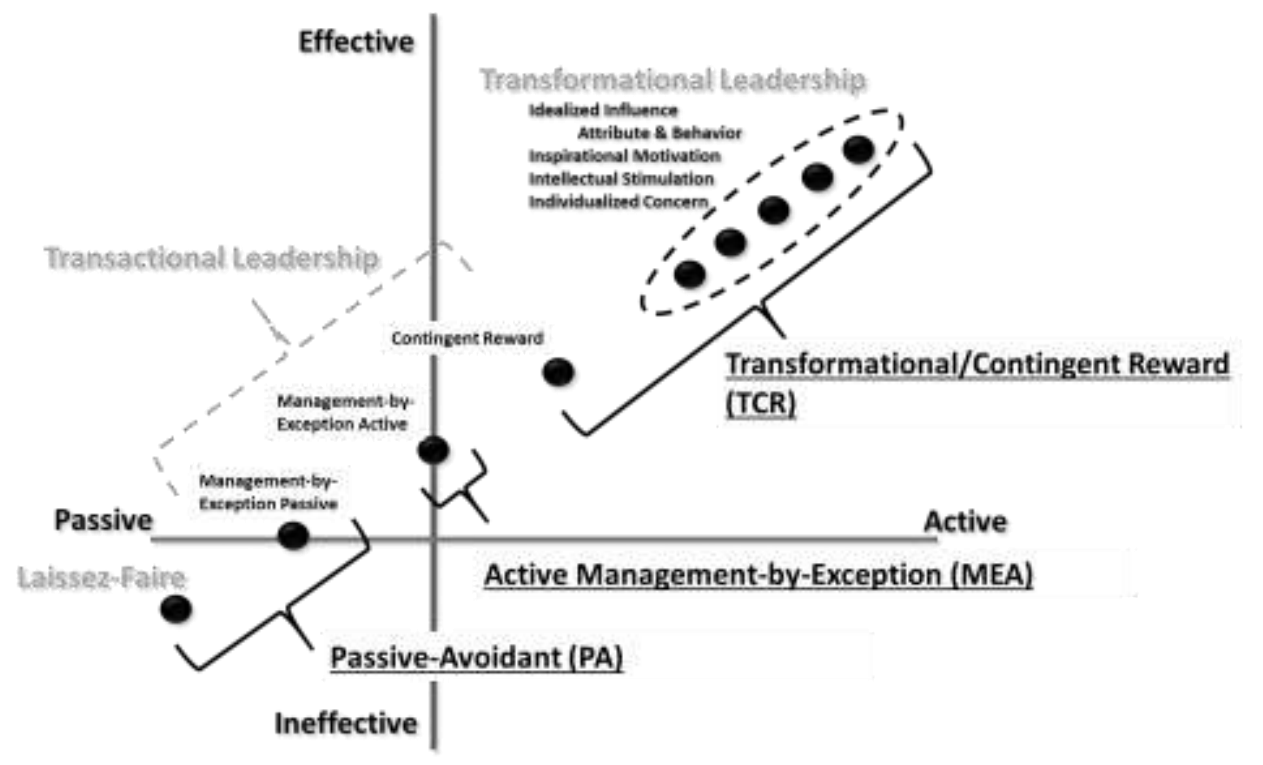

Figure 1: Modified Full Range of Leadership; adapted from $^{29}$

To account for current conceptualizations of leadership, engineers and engineering educators may need to look beyond the historically vertical, individual leadership perceptions of the past. Leadership has historically been considered an individual phenomenon where a single leader exerts leadership upon followers. ${ }^{30}$ Shared leadership, in contrast, characterizes leadership as an activity dispersed among members of an organization and the dynamic emergence of leaders within an organization or team. ${ }^{31}$ The emergence of the shared leadership paradigm accounts for the fact that in this modern age of increased technology and rapid industrial pace, it is nearly impossible for one person to have the knowledge, skills, and abilities for all aspects of highly intellectual work. ${ }^{8}$ Recent undergraduate engineering design team studies indicate that a shared leadership model may be more applicable than an individual, vertical model. Zafft et al. ${ }^{32}$ quantitatively determined that student design teams distribute leadership roles across multiple team members while Feister et al. ${ }^{33}$ found that engineering students describe leadership as emergent and fluid in their teaming experiences. This study accounted for this conceptual shift in leadership by examining team leadership from a shared perspective. 


\section{Data and Methods}

\section{Sample and Data Collection}

Student surveys were administered online during the 2014-2015 academic year at the end of the spring semester. Participants were enrolled in year-long, team-based, mechanical engineeringcentric, senior-level capstone design courses at three institutions: a large, mid-Atlantic research university (site A) and two smaller military institutions (sites B and C). Qualitative comparison of course syllabi and team charter requirements across the three institutions indicated similarity in the capstone design experience with regard to course objectives, course content, project requirements, and team-based pedagogy. Mechanical engineering was specifically chosen because of the discipline's professional interest in engineering leadership ( $\mathrm{see}^{3}$ ), mechanical engineering's prominence as the largest discipline for bachelor's degree attainment, ${ }^{34}$ and access to participant teams. The study had Institution Review Board approval at all three institutions.

This study's sample included 209 students (Table 1) who comprised 45 complete design teams; teams were only included if they exhibited a $100 \%$ response rate, which was a requirement for social network analysis. These 209 cases represent $46.5 \%$ of the total responses from the research sites. Site A had 118 participants (21 teams), site B had 58 participants (16 teams) and site $C$ had 33 participants ( 8 teams). 10 of the 45 teams were student-identified subteams of larger capstone projects. The teams were labeled mechanical engineering-centric because additional engineering disciplines were present within some teams. Although all participants were participating in mechanical engineering (ME) capstone design projects, 15 (7\%) of the participants were non ME majors; 8 students (4\%) were electrical engineering/computer science (EE/CS) majors, 3 were general engineering (GEN) majors (1\%), and 4 were from other engineering disciplines (2\%) (chemical engineering, civil/environmental engineering, and industrial/systems engineering). At Site A, 8 of the 118 students (7\%) were members of the Corps of Cadets, and all students at sites B and C were military officers in training.

Table 1: Sample Demographics

\begin{tabular}{|c|c|c|c|c|c|c|c|c|c|c|}
\hline Students & Teams & Asian & Black & Hispanic & $\begin{array}{c}\text { Native } \\
\text { American }\end{array}$ & $\begin{array}{l}\text { Pacific } \\
\text { Islander }\end{array}$ & White & $\begin{array}{l}\text { Multi- } \\
\text { Race }\end{array}$ & $\begin{array}{c}\text { Inter- } \\
\text { national }\end{array}$ & Male \\
\hline 209 & 45 & $6.7 \%$ & $2.4 \%$ & $7.2 \%$ & $0.0 \%$ & $0.0 \%$ & $78.9 \%$ & $4.8 \%$ & $3.3 \%$ & $90.9 \%$ \\
\hline
\end{tabular}

To maintain team level responses, 159 missing dyadic responses to leadership ratings (i.e., team member rating of another team member) (less than $1 \%$ of dyadic responses) were imputed through a form of mean substitution. Other methods of imputation were not applicable because the participant response referenced an external individual rather than being generated internally. ${ }^{35}$ These missing dyadic ratings were replaced by the mean rating of the rest of the team members regarding the rated individual.

\section{Variables}

To consider leadership across a full range of behaviors in our rate the members approach, we used a 14-item leadership scale developed in ${ }^{9}$ that was derived from the Multifactor Leadership Questionnaire. ${ }^{20}$ Students were asked to rate their teammates and faculty advisor in a round- 
robin (360 degree) fashion on these 14 leadership descriptive statements using a five point Likert-type scale: $1=$ Not at all; $2=$ Once in a while; $3=$ Sometimes; $4=$ Fairly Often; 5=Frequently if not always (see Figure 2).

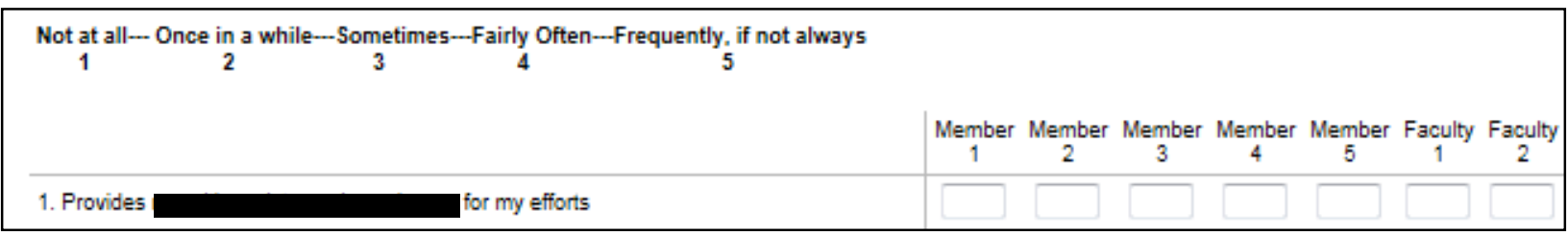

Figure 2. Sample round-robin survey item (redacted because of copyright agreement).

The round-robin survey data provided by the students across the 14 items were partitioned into scale variables representing intra-team relationships in TCR, MEA, and PA leadership scales identified by Novoselich and Knight ${ }^{9 ; 12}$ (Table 2). To calculate the scale scores, leadership behavior ratings were averaged across all team members so that each team member and the faculty advisor had a team average leadership rating attributed to them for each scale.

Table 2: Leadership Scale Variables

\begin{tabular}{|c|c|c|c|}
\hline Leadership Scale & FRLM Factor & $\begin{array}{l}\text { MLQ } \\
\text { Item* }\end{array}$ & Alpha \\
\hline \multirow{6}{*}{$\begin{array}{l}\text { Transformational/ Contingent } \\
\text { Reward (TCR) }\end{array}$} & Individualized Concern & 31 & \multirow{6}{*}{0.92} \\
\hline & Intellectual Stimulation & 32 & \\
\hline & Inspirational Motivation & 26 & \\
\hline & Contingent Reward & 35 & \\
\hline & $\begin{array}{l}\text { Idealized Influence } \\
\text { (Behavior) }\end{array}$ & 14 & \\
\hline & $\begin{array}{l}\text { Idealized Influence } \\
\text { (Attributed) }\end{array}$ & 10 & \\
\hline \multirow{4}{*}{$\begin{array}{l}\text { Active Management by Exception } \\
\text { (MEA) }\end{array}$} & \multirow{4}{*}{$\begin{array}{l}\text { Management by Exception } \\
\text { (Active) }\end{array}$} & 22 & \multirow{4}{*}{0.82} \\
\hline & & 27 & \\
\hline & & 4 & \\
\hline & & 24 & \\
\hline \multirow{4}{*}{ Passive-Avoidant (PA) } & Laissez-Faire & 5 & \multirow{4}{*}{0.88} \\
\hline & \multirow{2}{*}{$\begin{array}{l}\text { Management by Exception } \\
\text { (Passive) }\end{array}$} & 12 & \\
\hline & & 3 & \\
\hline & Laissez-Faire & 7 & \\
\hline
\end{tabular}

*Item text not included because of copyright agreement.

To operationalize shared leadership in this study, we interpreted shared leadership as a network of dyadic relationships, often described as a rate the members approach. ${ }^{36}$ We used social network analysis of individual team member round-robin data (i.e., 360-degree data in which each member rates all other team members $)^{36-39}$ to measure the degree to which leadership is shared within the teams. Conforming with the recommendations of Mayo et al. ${ }^{40}$, two measures of shared leadership were used: 1) network centralization (i.e., a measure of cohesion of the leadership network) and 2) network density (i.e., proportion of influence relationships 
within the team compared to the total possible $)^{36 ; 40}$. Following recommendations of Gockel and Werth $^{36}$ subtracting network centralization values from one produce a measure of network decentralization; a zero value represents individual (vertical) leadership, and a one represents leadership that is fully distributed across the team ${ }^{36}$ (see depiction in Figure 3). Teams with high levels of decentralization (distribution of leadership across the team) and density (amount of leadership within the team) enact shared leadership ${ }^{40}$ (see depiction to right of Figure 3 ). Network analysis proceeded using the SNA package in R. The team member ratings across the three separate scales were analyzed to determine the network decentralization and network density for each of the three leadership networks. A total of six shared leadership measures resulted: TCR decentralization, TCR density, MEA decentralization, MEA density, PA decentralization, and PA density.

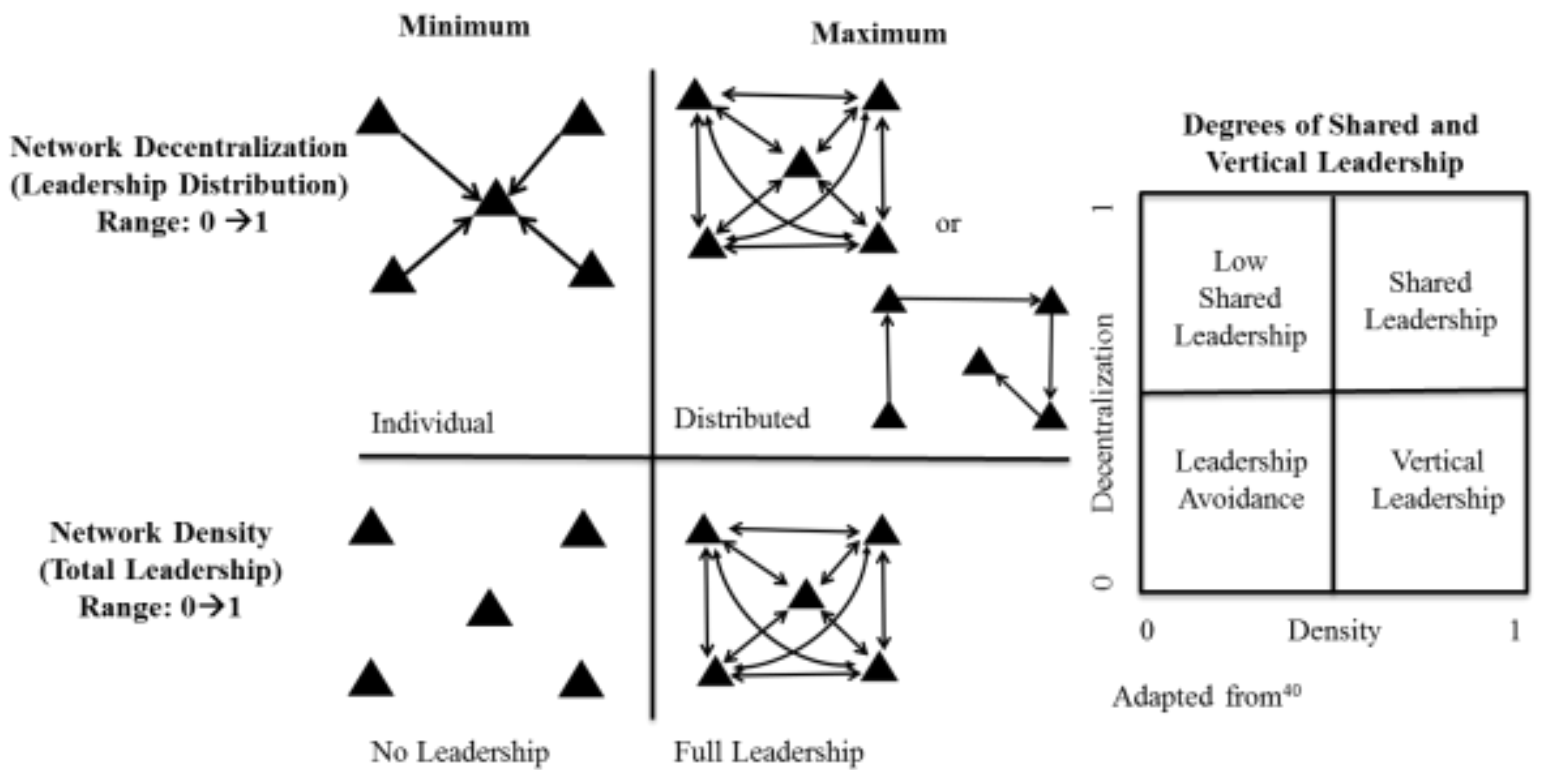

Figure 3: Shared leadership measure examples.

To address research question one, we examined the intra-class correlations ${ }^{41 ; 42}$ of the six shared leadership measures using SPSS v23. The intra-class correlation explained the proportion of variance in the shared leadership measures attributed to grouping the teams in various ways. We contrasted the amount of total variance explained by grouping the teams by institution and by military or civilian status to determine which groupings of the teams explained greater variance.

To address research question two, we used a Mann-Whitney $U$ test to determine statistically significant differences in rankings of teams based on the six shared leadership measures across team groupings. The relatively low number of teams that reported for this study prevented a normal distribution of shared leadership measures across the team groupings, making the nonparametric Mann-Whitney U test appropriate. ${ }^{43}$ Contrasting significant differences in decentralization and density measures separately allowed us evaluate both the distribution and amount of leadership separately. 


\section{Limitations}

There are a number of limitations to consider when interpreting the results of this study. First, this study only investigates senior-level capstone design teams with a majority of mechanical engineering students; additional investigation is required to generalize the results to other engineering disciplines or class years. Second, this study investigates a 14-item subset of the MLQ; directly comparing the results of this study to other research using the MLQ should take the differences in data collection into consideration. Third, this study only investigated civilian and military engineering design teams separately, consequently, claims cannot be made regarding how civilian and military students may interact when combined in the same team. Investigating how individual civilian and military students enact leadership was beyond the scope of this study and an area of future research for the authors. Finally, although this study investigated differences in leadership across civilian and military design teams, the effectiveness of the team leadership enacted by the teams was beyond the scope of this study and is an area of on-going research for the authors.

\section{Results}

Addressing research question one regarding whether institution or civilian vs. military grouping (combining sites B and C into one single group) explained more variance in shared leadership, intra-class correlations $(\rho)$ of the six shared leadership measures indicated that civilian-military groupings explained slightly more variance than institution groupings. The intra-class correlation for civilian-military grouping of the capstone design teams (Table 3) were only slightly higher than the institution level groupings (Table 4) for TCR decentralization, TCR density, and MEA decentralization. The remainder of the six shared leadership measures showed no variance explained by either grouping. Because civilian-military differences across the three institutions explained slightly more variance than institution level differences, analyses to address research question 2 proceeded using the civilian and military grouping of teams instead of by specific institutions.

Table 3: Intra-class Correlation Summary (Civilian vs. Military Groupings)

\begin{tabular}{|c|c|c|c|c|c|c|c|c|}
\hline & Level 1 n $\mathbf{~ L e v e l ~ 2 ~ n ~}$ & $\boldsymbol{\tau}$ & Wald Z & \multicolumn{2}{c|}{ p } \\
\hline TCR Decentralization & 45 & 2 & 0.01 & 0.60 & 0.55 & 0.03 & 0.20 \\
TCR Density & 45 & 2 & 0.00 & 0.57 & 0.57 & 0.02 & 0.15 \\
MEA Decentralization & 45 & 2 & 0.00 & 0.50 & 0.62 & 0.03 & 0.10 \\
MEA Density & 45 & 2 & 0.00 & N/A & N/A & 0.02 & N/A \\
$\begin{array}{c}\text { PA/LF Decentralization } \\
\text { PA/LF Density }\end{array}$ & 45 & 2 & 0.00 & N/A & N/A & 0.04 & N/A \\
\hline
\end{tabular}

Table 4: Intra-class Correlation Summary (Institution Groupings)

\begin{tabular}{|c|c|c|c|c|c|c|c|}
\hline & Level 1 n & Level 2 n & $\tau$ & Wald Z & $\mathbf{p}$ & $\sigma^{2}$ & $\boldsymbol{\rho}$ \\
\hline TCR Decentralization & 45 & 3 & 0.01 & 0.80 & 0.42 & 0.03 & 0.19 \\
\hline TCR Density & 45 & 3 & 0.00 & 0.67 & 0.50 & 0.02 & 0.14 \\
\hline MEA Decentralization & 45 & 3 & 0.00 & 0.52 & 0.60 & 0.03 & 0.06 \\
\hline MEA Density & 45 & 3 & 0.00 & N/A & N/A & 0.02 & N/A \\
\hline PA/LF Decentralization & 45 & 3 & 0.00 & N/A & N/A & 0.04 & N/A \\
\hline PA/LF Density & 45 & 3 & 0.00 & N/A & N/A & 0.00 & N/A \\
\hline
\end{tabular}


In addressing research question two regarding significant differences in shared leadership for teams at civilian institutions, results of Mann Whitney U tests indicated that statistically significant $(\alpha=0.05)$ differences exist only in the distribution (i.e., decentralization) and amount (i.e., density) of TCR leadership (Figure 4). Within the design teams, the 21 civilian teams exhibited greater distribution and amount of TCR leadership than the 24 military teams, which translates to more shared TCR leadership. No significant differences were identified between civilian and military design teams with regards to either MEA or PA leadership.

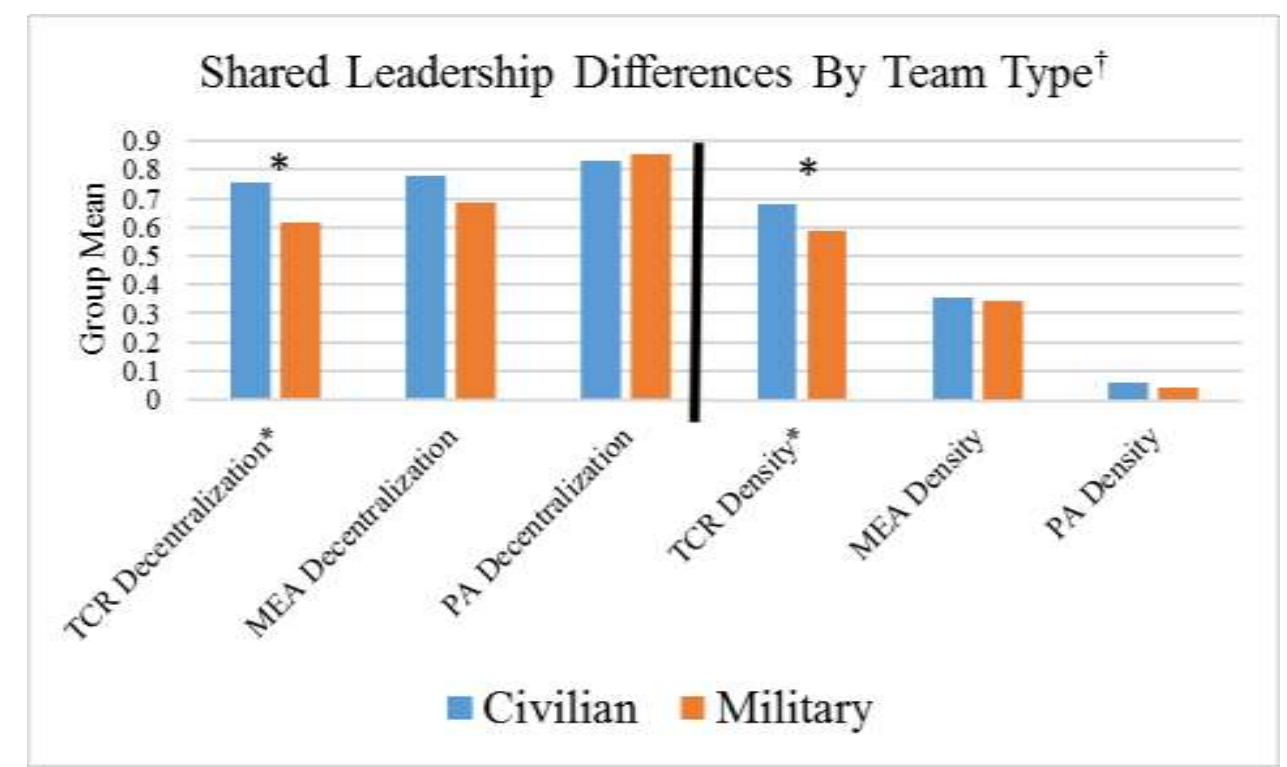

Figure 4: Comparison of Shared Leadership Measure Means by Team Type. $*=$ significant differences in group rank at the $\mathrm{p}=0.05$ level (two-tailed).

${ }^{\dagger}$ Group means are more readily interpretable and shown in the figure although the Mann Whitney U test actually compares mean group ranks.

\section{Discussion}

The results show that statistically significant differences exist in how military and civilian design teams share leadership. Specifically, civilian capstone design teams investigated in this study exhibited more shared leadership than their military counterparts with respect to the TCR form of leadership. Reflecting on the nature of military leadership, these results are not surprising. The lower TCR decentralization and TCR density measures for the military design teams provide indications that these teams enact somewhat more centralized or vertical leadership than their civilian counterparts. Centralizing leadership to fewer individuals would result in less distribution and amount of leadership within the teams. This tendency may be a by-product of students' intensive military leadership training. Military organizations are often associated with more vertical approaches to leadership. ${ }^{23}$ For the other two forms of leadership examined, this study indicates minimal differences between formative military and civilian capstone design leadership experiences.

Findings from analyses addressing research question one show that institutional differences account for nearly identical levels of variance as civilian-military differences. The results of analyses addressing research question two showed no differences in two of the three forms of 
leadership incorporated within this study. Correspondingly, for engineering educators and engineering practitioners, these results show that making broad assumptions regarding differences in undergraduate educational differences related to military vs. civilian institutions may be problematic. Undergraduate learning outcomes are influenced by many different factors, as explained by Terenzini and Reason ${ }^{44}$ The institution is only one of those potential sources of influence and often times is at a level too far removed from students' learning experiences to characterize specific educational environments. ${ }^{45}$ For MEA and PA leadership, this study indicates that students enact these forms of leadership similarly regardless of institution or civilian/military differences.

\section{Conclusions}

This study identified differences in the shared leadership enacted by civilian and military mechanical engineering capstone design teams. Although the leadership development curricula of students in military and civilian institutions may differ greatly, these differences may only translate to the engineering design context with regards to TCR leadership. Teams differed significantly in the level of shared TCR leadership enacted within their teams. Shared MEA and PA leadership showed non-significant differences. Additional research is needed to determine what aspects of the varied leadership development programs contribute to the observed differences in TCR leadership. For engineering education practitioners wishing to tailor engineering leadership experiences for their students during capstone design courses, these findings may indicate that best practices in design team leadership with regard to MEA and PA leadership may translate across civilian and military institutions and are worthy of consideration. For engineering education researchers, the results show that civilian-military differences should be taken into consideration when studying students' leadership processes in team-based courses.

\section{References}

1. National Academy of Engineering. (2004). The Engineer of 2020: Visions of Engineering in the New Century. In. (Washington DC, National Academies Press.

2. National Academy of Engineering. (2005). Educating the Engineer of 2020: Adapting Engineering Education to the New Century. In. (Washington, DC, National Academies Press.

3. ASME Center for Education. (2011). Vision 2030 Creating the Future of Mechanical Engineering Education. In. (New York, American Society of Mechanical Engineers.

4. Shuman, L.J., Besterfield-Sacre, M., and Mcgourty, J. (2005). The ABET "Professional Skills" - Can They Be Taught? Can They Be Assessed? Journal of Engineering Education, 41-55.

5. Hanus, J., and Russell, J.S. (2007). Integrating The Development Of Teamwork, Diversity, Leadership, And Communication Skills Into A Capstone Design Course. In ASEE Annual Conference and Exposition. (Honolulu, HI, American Society for Engineering Education.

6. Howe, S., and Wilbarger, J. (2006). 2005 National survey of engineering capstone design courses. In American Society for Engineering Education Annual Conference and Exposition, ASEE, ed. (Chicago, IL, ASEE), pp 5-10. 
7. Bayless, D.J., and Robe, T.R. (2010). Leadership education for engineering students. In 40th ASEE/IEEE Frontiers in Education Conference, IEEE, ed. (Washington DC, IEEE), pp S2J-1-S2J-6.

8. Pearce, C.L. (2004). The future of leadership: Combining vertical and shared leadership to transform knowledge work. The Academy of Management Executive 18, 47-57.

9. Novoselich, B.J., and Knight, D.B. (2015). Sharing the Full Range of Leadership in Student Teams: Developing an Instrument. In American Society for Engineering Education Annual Conference and Exposition. (Seattle, WA, ASEE.

10. Born, D.H., Phillips, A.T., and Trainor, T.E. (2012). America's service academies, your service academies. Liberal Education 98, 46.

11. West, C. (2012). Teaching Leadership to Undergraduates: Lessons from U.S. Military Colleges. Journal of College Teaching \& Learning 9, 135-146.

12. Novoselich, B.J., and Knight, D.B. (Under Review). The Full Range of Leadership for Engineering: Examining a subset of the Multifactor Leadership Questionnaire for mechanical engineering capstone design teams. Journal of Engineering Education.

13. Farr, J.V., and Brazil, D.M. (2009). Leadership Skills Development for Engineers. Engineering Management Journal 21, 3-8.

14. Farr, J.V., and Brazil, D.M. (2012). Leadership skills development for engineers. IEEE Engineering Management Review 40, 13-22.

15. Rottmann, C., Sacks, R., and Reeve, D. (2014). Engineering Leadership: Grounding leadership theory in engineers' professional identities. Leadership.

16. Dorst, K. (2008). Design research: a revolution-waiting-to-happen. Design Studies 29, 4-11.

17. U.S. Government Accounting Office. (2013). Military Personnel: Actions Needed to Improve Evaluation and Oversight of Reserve Officers' Training Corps Programs. In. (Washington D.C. , GAO.

18. Sniders, D.M., Priest, R.F., and Lewis, F. (2001). The Civilian-Military Gap and Professional Military Education at the Precommissioning Level. Armed Forces \& Society 27, 249272.

19. Bass, B.M., and Avolio, B.J. (1994). Improving Organizational Effectiveness Through Transformational Leadership.(Thousand Oaks: Sage).

20. Bass, B.M., and Avolio, B.J. (2013). Multifactor Leadership Questionnaire: The benchmark measure of transformational leadership. In. (Menlo Park, CA, Mind Garden Inc.

21. Bass, B.M. (1985). Leadership and Performance Beyond Expectations.(New York: Free Press).

22. Douglas, K.A., and Purzer, Ş. (2015). Validity: Meaning and Relevancy in Assessment for Engineering Education Research. Journal of Engineering Education 104, 108-118.

23. Avolio, B.J., Sivasubramaniam, N., Murry, W.D., Jung, D.I., and Garger, J.W. (2003). Assessing Shared Leadership. In Shared Leadership: Reframing the Hows and Whys of Leadership, C.L. Pearce and J.A. Conger, eds. (Thousand Oaks, Sage ), pp 143-172.

24. Breaux, P.J. (2006). An effective leadership approach for today's engineer In IEEE/UT Engineering Management Conference. (Austin, TX, IEEE), pp 61-65.

25. Avolio, B.J., Bass, B.M., and Jung, D.I. (1999). Re-examining the components of transformational and transactional leadership using the Multifactor Leadership Questionnaire. Journal of Occupational and Organizational Psychology 72, 441-462.

26. Boies, K., Lvina, E., and Martens, M.L. (2010). Shared Leadership and Team Performance in a Business Strategy Simulation. Journal of Personnel Psychology 9, 195-202. 
27. Antonakis, J., and House, R.J. (2002). The Full-Range Leadership Theory: The Way Forward. In Transformational and Charismatic Leadership: The Road Ahead, B.J. Avolio and F.J. Yammarino, eds. (New York, JAI), pp 3-34.

28. Avolio, B.J. (2011). Full Range Leadership Development.(Washington D.C.: Sage).

29. Northouse, P.G. (2013). Leadership: Theory and Practice.(Thousand Oaks, CA: Sage).

30. Markham, S.E. (2012). The evolution of organizations and leadership from the ancient world to modernity: A multilevel approach to organizational science and leadership. The Leadership Quarterly 23, 1136-1151.

31. Pearce, C.L., and Conger, J.A. (2003). Shared leadership: Reframing the hows and whys of leadership.(Thousand Oaks, CA: Sage).

32. Zafft, C.R., Adams, S.G., and Matkin, G.S. (2009). Measuring Leadership in Self Managed Teams using the Competing Values Framework. Journal of Engineering Education July, 273-282.

33. Feister, M.K., Zoltowski, C.B., Buzzanell, P.M., Oakes, W.C., and Zhu, Q. (2014). Leadership in Multidisciplinary Project Teams: Investigating the emergent nature of leadership in an engineering education context. In 121st ASEE Annual Conference \& Exposition. (Indianapolis, IN, American Society for Engineering Education

34. Yoder, B.L. (2014). Engineering by the Numbers. In. (Washington, DC., American Society for Engineering Education.

35. Huisman, M. (2009). Imputation of missing network data: some simple procedures. Journal of Social Structure 10, 1-29.

36. Gockel, C., and Werth, L. (2010). Measuring and Modeling Shared Leadership Traditional Approaches and New Ideas. Journal of Personnel Psychology 9, 172-180.

37. D'Innocenzo, L., Mathieu, J.E., and Kukenberger, M.R. (2014). A Meta-Analysis of Different Forms of Shared Leadership-Team Performance Relations. Journal of Management, 0149206314525205.

38. Wang, D., Waldman, D.A., and Zhang, Z. (2014). A meta-analysis of shared leadership and team effectiveness. The Journal of applied psychology 99, 181-198.

39. Nicolaides, V.C., LaPort, K.A., Chen, T.R., Tomassetti, A.J., Weis, E.J., Zaccaro, S.J., and Cortina, J.M. (2014). The Shared Leadership of Teams: A meta-analysis of proximal, distal, and moderating relationships. The Leadership Quarterly 25, 923-942.

40. Mayo, M., Meindl, J.R., and Pastor, J.-C. (2003). Shared Leadership in Work Teams. In Shared Leadership: Reframing the hows and whys of leadership, C.L. Pearce and J.A. Conger, eds. (Thousand Oaks, CA, Sage), pp 193-214.

41. Snijders, T.A.B., and Bosker, R.J. (2012). Multilevel Analysis: An introduction to basic and advanced multilevel modeling.(Washington, DC: Sage).

42. Peugh, J.L., and Enders, C.K. (2005). Using the SPSS Mixed Procedure to Fit CrossSectional and Longitudinal Multilevel Models. Educational and Psychological Measurement 65, 717-741.

43. Howell, D.C. (2013). Statistical Methods for Psychology.(Belmont, CA: Wadsworth).

44. Terenzini, P.T., and Reason, R.D. (2010). Toward a more comprehensive understanding of college effects on student learning. In Annual Conference of the Consortium of Higher Education Researchers (CHER). (Oslo, Norway, Consortium of Higher Education Researchers.

45. Ro, H.K., Terenzini, P.T., and Yin, A.C. (2013). Between-College Effects on Students Reconsidered. Research in Higher Education 54, 253-282. 